\title{
ウサギ食細胞におけるインターフェロンの産生
}

\author{
甲野雄次

\section{INTERFERON PRODUCTION IN RABBIT PHAGOCYTES}

Yuji KONO

National Institute of Animal Health, Kodaira, Tokyo

生体内で血中に出現するインターフェロン (IF) を産 生する細胞がいる゙れの細胞であるか険討した結果，網 内系細胞(RES) がその主役であるらとの結諭を得た ${ }^{1-3)}$ 。

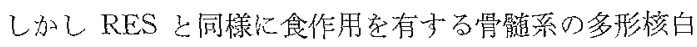
血球の役割はいまだ明らかでなかった。

そこで，多形核白血球を主体とするウサギ腹腔細胞， 大食細胞主体とするウサギ腹腔細胞, ウサギ腎培養細 胞，およびウサギの生体内に款汀る IF 産生の状況学比 較し，食作用を有与る細胞が生体内での IF 産生にいか に関与するか考考察した。

ウサギ腹腔細胞は約 $3 \mathrm{~kg}$ のウサギの腹腔に約 $500 \mathrm{ml}$ の 4 \%の馬鈴しよデン粉液を注入し，その 1 日または 4 日後に開腹して得た。2 回の遠心沈殿を繰返えして得た 細胞の塗抹標本をギムザ染色して細胞分類を試みた結果 デン粉注入後1日目に得た腹腔細胞 (1日RPC) は $95 \%$ が多形榜白血球であり，5\%が単核細胞であつた。4日 目に得た腹腔細胞（4日 RPC）は $80 \%$ の単核細胞と $20 \%$ の多形核白血球よりなっていた。

このような組成老持つ細胞索1日 RPC・1.5×107，4 日 $\mathrm{RPC} ・ 1.8 \times 10^{7}$ 亿るなよらに牛血清に浮遊し部分精 成した NDV (TCND 株) を接種した。その細胞当り 接種ウイルス量(m.o.i.) 岋それぞれ 4.3，3.6であつた。 この細胞浮遊液を水平振䔽しつつ $37^{\circ} \mathrm{C}$ で培養し, 図示 した時間にその $1 \mathrm{ml}$ ずつ存取出し IF 被検試料とした。 ウサギ腎 (RK) 培養では $200 \mathrm{ml}$ 容量角型培養瓶交たり の細胞数は $1.2 \times 10^{7}$ で为つた。RK 培養では接種ウイ ル大量が少ないと IF 産生が著しく遅く,かつ低くなる ことが経験上明らかであつたので，この䇲験では m.o.i. 30 意用いた。生体内での IF 産生には約 $2 \mathrm{~kg}$ のウ少ギ を用い，その耳静脈に $10^{9.4}$ TCD 50 の NDV を接種し 血清の IF 佂の消長をしらべた。

このような IF 被検試料はすべて活性の NDV を大 量化含んでいたので，いずれも1/20 量の抗 NDV 血清

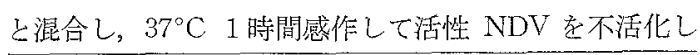
鋠林省家畜衛生陚験場

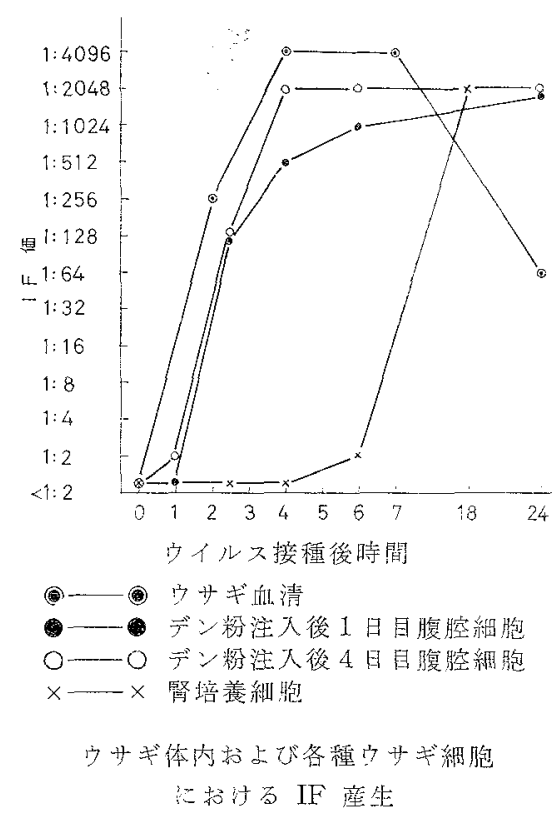

た後 IF 証明に用いた。IF 証明は CPE 抑制法によっ た。すなわ方 2 倍累代希釈 した IF 被検試料 $0.3 \mathrm{ml}$ 字 各 2 本の RK 培養試験管 $(1.2 \times 10 \mathrm{~cm})$ に注入し, $37^{\circ} \mathrm{C}$ 18 時間培養した後 $10^{4} \mathrm{TCD} 50$ の西部门マ脑炎ウイルス を用いて政撃した。刘照培䖉が攻馨ウイルスにより完全 に破壊された時に判定を行ない，1組 2 本の培養が共に 約 $50 \%$ 委を法それ以下の細胞变性を示した被検試料の最 高希釈を IF 価とした。

結果は図にみられるように，ウサギ生体内の IF 価住 ウイルス接種 2 時間後より急上昇し， $4 \sim 7$ 時間で最高 値，1：4096に達し，その後減少した。1日 RPC およ び4 日 RPC は共にほぼ同一の産生状況を示し, 接種後 1 時閒目より徐々に上昇し始め，2.5 時閒では急激な増 加を示し 1：128 となつた。 4 日 RPCでは 4 時間後には ほぼ IF 産生の頂点に達し1：2048 となつた。1 日RPC で柱4 日 RPC に比しやや緩い曲線を画いて IF は増加 し，4 時間で $1: 512 ， 6$ 時間で 1: 1024となり，24 時 
間後に最高の1：2048となつた。ウサギRK培食で活 6 時閐後にいたり初めて検出し得る IF が産生され，その 後 18 時間目までに急激に増加し最高值は RPCと同じく 1: 2048 に達した。

この実験は完全に単一な細胞を用いたものではなかつ たが，体内にお打る状沅と近、条件にある骨髄系の多形 核白血球も，RES に属子る大食細胞も共にウイルス接 種後非常に早い時期に IF 学産生することを示してい る。これら RPC での IF 産生の型はウサギ血清中への IF の出現の型と全く一致しており, 今まで IF 産生の 母細胞七して考えられていた RES ${ }^{1-3}$ 以外に骨髄系の細 胞昌生体内での IF 産生に参加している可能性を示唆し

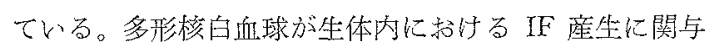
しているかどうが，この細胞とウイルスの体内での相 互反忘が明らかになつた後に結論されるべきで岁るが， Mims ${ }^{4)}$ によると体内に侵入した，亦るい性接種された
ウイルスと多形榜白血球との反応は，多くは知られてい ないが，大食細胞 (macrophage) がはたす役割の重要さ に比較するときわ柾限定されていると考光られてい る。それ故，現在では，ウイルスが血流中に侵大した

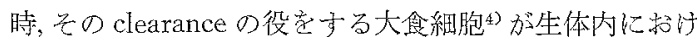
るIF 産生の主役孝はたしていると考光得るであるう。 他方 RK 培養での IF 産生注生体内抒よび RPC での それに比し著しく荱くここの種の細胞が血清中に出現す る IF の産生に関与するとは考光られない。

\section{文献}

1) Kono, Y-, and Ho, M. : Virology, 25. 162. 1965. -2) Kono, Y.: Nat. Inst. Anim. Hlth Quart., 6, 241. 1966. -3) Kono, Y. : Proc. Soc. Exp. Biol. Med., 124. 155. 1967. -4) Mims, C. A. : Bact. Rev., 28, 30, 1964. 